\title{
A Study on the Effects of Ghazan Khan's Reformative Measures for the Settlement of the Nomadic Mongols (1295-1304)
}

\author{
Roohollah Ranjbar ${ }^{1}$, Fereydoon Allahyari ${ }^{1} \&$ Hussein Mir Ja'fari ${ }^{1}$ \\ ${ }^{1}$ History Department, University of Isfahan, Isfahan, Iran \\ Correspondence: Roohollah Ranjbar, History Department, University of Isfahan, Isfahan, Iran. Tel: \\ 98-917-133-2598. E-mail: Roohollaranjbar@yahoo.com
}

Received: December 1, 2012

Accepted: February 20, 2013 Online Published: March 22, 2013

doi:10.5539/ach.v5n2p77

URL: http://dx.doi.org/10.5539/ach.v5n2p77

\begin{abstract}
This article aims to elaborate the effects of Ghazan Khan's reformative measures for changing Mongol lifestyle. They migrated from one place to another to make a living but after his reforms, they were settled. Mongols were among the people who lived in the Central Asia usually made raids on the neighboring nations. They had taken to a life of vagrancy and never wanted to be settled in a particular place. When they entered the civilized Persia, the Mongolian government became highly polarized. On the one hand, the Mongols habitually destroyed the government's sources of income (agriculture and trade), and on the other, they were its military force, whose existence was a necessity. As this polarization continued, political and economic crises emerged, too. Then, Ghazan Khan, by some actions, hindered the collapse of the Ilkhanate. As a result, the Mongols underwent a self-imposed settled life but it was against the great Yasa code of Genghis Khan.
\end{abstract}

Keywords: Mongols, the Ilkhanate, Ghazan Khan, Oljaytu, settlement

\section{Introduction}

During its different historical eras, a period of several thousand years, Iran's peoples and social structures have suffered many changes due to a variety of factors. In the past, Iran connected the old west and east worlds because of its vastness and its strategic position. As a result, different peoples had to move across the land of Iran, and some chose it as their ultimate settlements. The Greeks, Arabs, Turks and finally the Mongols profited from such a situation. Some of these peoples, having achieved their goals, preferred staying permanently than immigrating to other places, bringing about thorough changes in Iran's social system, habits and customs, lifestyles, etc. The Mongols were the most important and the last people who invaded and stayed in Iran. They changed Iran's social system and, naturally, theirs had to change, too.

The Ilkhanid's sovereignty in Iran was part of the great empire under the command of Genghis Khan and his successors. It extended broadly from Korea to Eastern Europe and China to Iran and Syria. Such conquest originated from Mongolia (Middle Asia), which was the original land of these homeless nomadic people. They lived by shepherding, hunting and sometimes looting nearby tribes or civilized centers. Roving lands was what they had been doing for centuries, and considered it the best lifestyle. The Mongolian tribes, who lived such a lifestyle, were the enemies of the villagers and townspeople. They were always on the move and had no intension of settlement. When they reached a town, they destroyed it. Genghis Khan wanted the conquered places just for livestock's pasture and his tribe's hunting ground. He didn't have the imagination of a life based on agriculture and settlement in large cities. He denied the civilization and its luxuries, even after conquering largest cities of china. He preferred staying at the tent to living in palaces. It is known that the Mongols obeyed the order of Genghis Khan on refraining from settlement. And there were some leaders, who, abiding by this rule, refrained from permanent settlement after their conquests. Inconformity of the Mongols with the style of life in conquered places made the Mongol's rulers confused in making a clear decision on the settlement issue. The nomadic lifestyle of the Mongols, then the dominant power in Iran, scared away the Persian peasant subjects, an important source of income for the Mongol government, from their homes and lands, thus rendering them poorer. Moreover, curbing their own nomadic lifestyle meant weakening the military structure of their government, the strengthening of which was an essential affair at that time of history. And as a result of frequently being in tight political, social and economical situations, it didn't take long for the nomadic Mongols and their leaders to give up their old lifestyle and take to the settled urban life that their Persian subjects lived. Of historical importance 
are the stages and factors which ultimately impelled these harsh nomads to take up settlement, peace and coexistence with the conquered.

In this research, by focusing on Ghazan Khan Era and relying on his corrective actions, we intend to explain the effect of these actions on settling the new style of life by immigrant Mongols. For making comprehensive study on this subject, first we want to mention some points about social structure in Mongols era and Iran's social situation before Ghazan Khan's era.

\section{Mongols and Civilization}

When Sultan Mohammad Kharazmshah was returning from a futile fight with the Abbasid Caliph to his territory, he had no idea whatever that his brave soldiers were to be soon defeated, and that his dynasty, established by the great efforts of his ancestors, was to collapse by a nomadic tribe. This nomadic tribe emerging from the forgotten Gobi desert, soon expanded and became the super power of the then world. This new force were the Mongols, which gathered power under Genghis Khan Sovereignty in the Mongolia desert and in a short time changed the destiny of the great part of the world. With forests, plains and steppes, Mongolia covers a large part of the Pamir Plateau. Mostly cold and dry, it has the desert climate, long cold winters and short summer with lots of rain. The hillsides are covered with pines and cedars, but most of the land is the Gobi desert, of which some parts seldom receive any rain. In the Mongolian language, 'Gobi' means 'desert', salt flat and steppe. Its plants are exclusively thorn and weed, which partly feed camels in this desert. The temperature in this region of the world is very unstable, falling to -40 degrees $\mathrm{C}$ on some winter nights and rising to +38 degrees $\mathrm{C}$ on some summer days. These extreme changes in the weather results in rarifying the atmosphere, in which making a fire is an impossibility (Bayani, 2001). Besides the cold climate and the rarified atmosphere, hurricanes and snowstorms beset the land, destroying everything that happens to be on their way, and, presenting a constant challenge to man and animal, cause life very hard for people and farm animals there.

Men living in this harsh land have certain characteristics, the lack of which makes life impossible for the outsiders. Very limited livestock raising took place in such a cold climate and land, and most people made a living by hunting and fishing. The concept of civilization was alien to the Mongols and their manner of life had remained unchanged for long centuries. The Huns rose from this harsh land, and in the first half of the 5th century could reach The Roman Empire borders. Amin Marslen, the Latin historian, taking an interest in them, described them in this way: "they are short but have muscular bodies; their torsos are massive and their heads abnormally large; they truly resemble demons, and they live like animals" (Grousset, 1990). A century later in $581 \mathrm{AD}$, a Chinese historian presented a more positive picture of this people, informing us that they wore their hair long, lived in felt tents and wandered about in search of water and pasture, their most important affair being hunting and raising cattle. And, adds this historian, having no idea of religion and justice, they resembled the Xiongnu (or the Huns) in this respect (Grousset, 1990). A similar picture has been drawn of these Central Asian people's appearance and manner of life some 650 years later by John De Plano Carpini, the Pope's ambassador (Carpini, 1903). Savagery, a life depending on stealth and robbery, and nomadic lifestyle were the most important characteristics of the people in this part of the world, quite remarkable to historians and explorers. Amin Marslen was of the opinion that they were the most savage and bloodthirsty of all people, and the statement by Khabul Khan, the great grandfather of Genghis Khan who said '... killing is pleasing when in a massacre...', attests the Roman historian's opinion. As was mentioned, the particular climate of this large land renders ineffective any agricultural attempts; sporadic verdant pasture; however, provides the basis for livestock raising. But the shepherds and livestock tenders of these regions were constantly threatened not only by the terrible climate conditions, but also by their marauding neighbors. The Mongolians made a living mainly in two ways: hunting or breeding animals was one, the other, plundering and robbing people. These two different economic ways of living, naturally, caused conflicts between cattle breeding tribes and the hunting ones, the memories of the consequent struggles long remaining with the people. Livestock raisers bred cows, sheep, camels and, especially, horses, their dependence on horse being of utmost importance, to a degree that a horseless Mongol was hard to imagine (Hamedani, 1994). Both groups had to roam the deserts to make a living; they used to have this lifestyle for so many years, their spirit and culture being so ingrained with nomadism that non-nomadic, to them, meant extinction. For them living within the enclosure of walls and ramparts meant living in captivity; a superior life was a nomadic life, they believed (Grousset, 1990). The Mongol khans and their counselors decried whatever made people quit nomadism. They disagreed with Buddha and Lao Tzu because accepting their ideas would lead to mildness and clemency (Grousset, 1990). They had no use for luxury and pomp, since they believed that wealth and luxury brought laziness with them, hence, "a silver-studded cradle or a gold brocade eiderdown was wealth" (Hamedani, 1994). They would not get silk and silver without a toil; the only way they knew how to lay hands on them was by robbery. 


\section{The Tent and Its Importance for the Mongols}

Homes of the Mongols, both the stockbreeders' and the hunters', were similar, and were of great interest to anyone who laid eyes on them. It was a round tent, made of baize and supported by a central wooden pole. In the ceiling there was a hole to serve as a skylight (Carpini, 1903). These tents were easily assembled, and when it was time to go, quickly disassembled. Sometimes they were assembled on big carts, drawn by cows. Later on, when the Mongol population increased in the lands of China, Russia and Iran, the natives called these tents-on-carts 'the moving towns' (Ibn Battuta, 1969). They were, over so many years, so much used to living their nomadic life that even the idea of quitting it never crossed their minds. Neighboring these roaming, tent-dwelling Mongols, there were some other Mongols who would not live even in tents, neither did they care about stockbreeding. They hunted most of the time. They believed that living in a cities, villages and, even, plains was the utmost punishment incurred on oneself. Rashid ad-Din Fazlullah called them the 'nation of the woodland', as they lived their whole lives in the underbrushes and upon the trees (Hamedani, 1994). The Mongols were nomadic tribesmen when they entered Iran and remained so almost to the end of the Ilkhanid period. It was only at the end of the Ilkhanids that some of Ilkhans and tribesmen reluctantly stopped being nomadic tent-dwellers. They can't have done it willingly as they loved their tents and as their nomadic values and beliefs still persisted. The tearing of the tent, for example, or the falling of its pole was, to them, a catastrophe, indeed (Hamedani, 1994). It was in the tent that many khans came to be elected Ilkhans, and guests were entertained in the tent when they held parties. The increasing association with the nations of the conquered lands introduced a life of luxury into the tent, and it was one pricey gift of a tent that contented the Ilkhan. Erecting tents for the Ilkhans was an important ceremonial event with the Mongol khans and subjects. Arghun, the ruler of Khorasan, and Masoud Beik set up a lamé tent for Hulegu Khan when he entered Iran. With the Ilkhan's state responsibilities increasing, the shape and structure of tents were accordingly changed. Tents with waiting rooms and halls to receive people were made. Noblemen of the court, too, usually had their own tents in the camp (Hamedani, 1994). Since Mongols had their winter and summer migrations in large groups, extensive areas of the plain were spread over by their great number of tents wherever they decided to stay for a time. A city of tents came into being, indeed. One such city was Ojan (Bayani, 1379). When Mongols were acquainted with education and learned what pedagogy was, they devised mobile tent schools for the Mongol princes to go on the migration, as giving up the nomadic lifestyle was out of question for them (Al Kashani, 2006).

\section{The Mongols and Iran}

Genghis Khan's strategy in conquering cities included two approaches. The first was massacring the people, the second, spreading the news of the horrible massacre to the neighboring cities to intimidate the people into surrendering without any resistance (Sanders, 1994). Following the first approach, the Mongols didn't refrain from doing any crime and destruction. They had no mercy on anyone; they killed men, women and children; they even tore open pregnant women's abdomens and killed their babies (Ibn Athir, 1966). The best description of the Mongol criminal army has been given by Jamugha, where, in a talk with Tayan Khan he says:

My friend, Anda Temujin, has fed

four dogs (Jebe; Khubila; Jelme; Subete) with human flesh,

then held them back with iron chains.

These are the people who charge at us

pursuing our soldiers.

These four dogs have helmets of copper

snouts like chisels,

tongues like awls

hearts of iron

whips sharp as swords

These four dogs feed on the dew and ride on the winds.

These four, when they fight an enemy, feed on his flesh.

These four take human flesh as their share of the spoils.

(Anonymous, 1998).

The Mongols employed a variety of trickery in executing their massacres. Like the cat that plays with the mouse 
before killing it, they played with their victims first, and then committed them to their sharp swords. In the city of Merv, they took the inhabitants into the desert and distributed them among the soldiers. They were forced to genuflect, and then the Mongol soldier beheaded them with his sword (Juwayni, 1992). The blood bath that they ran there was on such a large scale. Joveiny has reported that Seyyed Ezzoddin Nassabé, a prominent figure of Merv, had been, for thirteen days, counting the number of the slaughtered, which amounted to one million and three hundred thousand (Juwayni, 1992). Hostility of the Mongols against the inhabitants of the cities they conquered had no limits. Ilkcheday Noyan, the Mongol warlord, having massacred the Heratis, when leaving the city of Herat, assigned a number of Mongol troops to lay in ambush in the city mosque. He, then, forced a muezzin to go up on the minaret to say the azan and summon the Muslims to the mosque. A few remaining Heratis, who had been hiding in cellars, channels and other hiding places, hearing the summons, thought that the Tatars had gone, so they hastened toward the mosque, where they were welcomed with drawn swords. The Mongols were very hostile to the prisoners, too, and when necessary, inflicted utmost cruelty even on corpses. In the conquest of the city of Tarmad, an old woman, in order to save her life, said that she had swallowed a pearl. The Mongols not only cut her stomach open, but also, on the order of Genghis Khan, cut open the remaining corpses' stomachs to find more pearls (Hamedani, 1994). Neyshabor, a culturally and economically prospering city, was so utterly devastated by Genghis Khan's daughter that "even the cruelest eyes cried at such a devastation," as Yaqut al-Hamawi recorded (al-Hamawi, 1970).

These reports are just a few and should be enough among the many instances to show the Mongol cruelty, as reporting the whole might lead to verbosity. As a result of such vast devastation and fear, wrought by Genghis Khan's occupation of Khorasan, no-one dared to settle in and choose as home the areas from Harat to Mazandaran, the territory, according to Petrushevsky, being half destroyed and half the den of wolves and lions, the remaining people having been eating for survival the flesh of man, dog and cat for a whole year (Petrushevsky, 1979).

Genghis Khan's second strategy, the terrible massacres of people, had created such an atmosphere of fear that the people of some cities surrendered to the Mongol force without any resistance whatever (Sanders, 1994). Thus this strategy not only kept the army strong, as there were no casualties, but also made the conquest of cities very quick. Genghis Khan's invasion of Iran ended and Sultan Mohammad Kharazmshah's death came about, but some of the Mongols stayed in Iran, for which the exact reason is not quite known, since Genghis Khan's aim was not Iran's entire conquest or to stay there. With an army of 129 thousand men he invaded and destroyed the cities of Iran one by one, just to punish Sultan Mohammad Kharazmshah. He, acting differently as a conqueror usually did, appointed a non-Mongol ruler of the same creed to the government of the surrendered cities. And, not intending to ensure his stay and sovereignty in Iran, he left no part of his army in these cities. Sultan Mohammad Kharazmshah having passed on, Genghis Khan had no just reason to stay in Iran; however, an unknown number of his troops stayed in Iran and especially in the Badgheis Garrison to kill Jalal ad-Din Kharazmshah or prevent his return to Iran. Genghis Khan's real intent in this mission was to repeat the same attempt with the Tatars, Merkits and Naymans. Though this attempt seems to be short-termed and the goals soon to be achieved, the troops' remaining in a strange territory was almost impossible without men's settlement there. Accordingly, the Mongols who remained in Iran and waited the return of Jalal ad-Din Kharazmshah, continued to behave in two different ways in the conquered land: inflicting oppression on the people, and managing the cities.

The Mongols depended on the local forces in the government of the cities, and avoided sending the limited number of soldiers they had at their command to distant places, but usually posted them at the city borders instead. The absence of the Mongols was well noticed by the native peoples, and some simple-minded, ignorant individuals, hoping to cast aside the symbolic Mongol sovereignty, rose against and had clashes with the Mongols, even killing some native Mongol-appointed rulers. The reaction of the Mongols to such actions was invariably the massacre of the rebellious population. Besides slaughtering the people and destroying the cities, they created more problems and hardship for the people; they annihilated the agricultural products and irrigational systems. These tragic events caused the townsmen and the countrymen to flee from their homeland and seek refuge in some safer places. Those who preferred staying in their hometown to abandoning it suffered still more calamities.

The Mongol nobles, having no proper experience in governmental management, habitually continued their usual robbing and plundering. Arriving at a village or town, a Mongol commander or agent occupied hundreds of houses for himself and his party. His servants took away all the valuables they could lay hands on in these homes, raped the family and made fun of and humiliated the owners (Hamedani, 1994). Townsmen and countrymen deliberately kept their houses in a dilapidated state so that the Mongol commanders and their hosts might dislike 
to enter and stay at such ruined places. This method was not quite effective since one leaving group of Mongols was immediately replaced by a new arriving one (Hamedani, 1994). Some Khorasanis built low entrances to their houses so that a horseman might not enter (Hamedani, 1994).

Alongside such barbarous behavior, some agents dispatched by the Khagans came for the administration of the cities. Most of them were of tribal Turks, like Gharakhtayis and Ovirats, who had racial consanguinity and lingual affinity with the Mongols. They knew what being civilized and urban meant, so they attempted, when settled in Khorasan, the reconstruction of cities and support of people to prevent further destructions. Distinguished cases of such constructive attempts were materialized in Khorasan by Korguz Uyghur, the Oktai Khagan appointed ruler of the territory. Joveiny, highly praising Korguz' ruling period, has called it, with some exaggeration, the time of stability and security. Korguz made the city of Toos his center of government and did so much for its development. Words has it that, as a result of such development, "a house originally sold at the price of two and a half Dinars, was sold, a week later, at two hundred and fifty" (Juwayni, 1992).

Although Korguz had been appointed by the Khagan and the Mongol agents were supposed to act under him and carry out his orders, they wantonly oppressed their Persian subjects, thus hindering the proper administration of Khorasan (Fazlullah, 1374). Korguz' attempts at developing the territory induced the Mongol princes to grow against him a grudge, climaxing in his capture and execution (ad-Din Fazlullah, 1374). It must be noted that an important accusation brought against him by the Mongols was his building castles (Joveiny, 1370). According to a Mongol belief and attitude, building and residing a castle literally meant rebellion against the Khagan (Aqsarayi, 1944). This might show why the Mongols felt so hostile toward the castle and castle-residing.

Korguz constructive attempts were followed by his successor, Prince Arghun. Arghun had been appointed by Töregene Khatun (Turakina Khatun), Oktai Khan's (Ögedei Khan) regent, to the government of the countries previously under Korguz: from The Amu Darya (Oxus) to the borders of Fars, and Georgia, Mosul and Anatolia. During his 15 year reign (1244-1256), he managed, though partially, to curtail the oppressive Mongol commanders' power in the cruel treatment of people.

\section{The Ilkhanids and Iran}

Prince Arghun's rule came to an end by the arrival of Hulegu Khan in Iran, but he remained in the service of the Ilkhans. Hulegu is known to be the founder of the Ilkhanid Dynasty in Iran; however, calling the rulers of this dynasty Ilkhans, and applying the concept of Ilkhanid to their government still remain open to dispute (Razavi, 2012). With Hulegu's arrival in Iran, administrative authority and military commandership merged in his person. His courage, warriorship, royal origin and Mongke Khan's direct support of his expedition to Iran brought about the unity of the Mongols in Iran, a unity which lasted even after Hulegu's death with the Mongols remaining faithful to his family.

Within the 80 year rule in Iran, the Ilkhanid central government took various political, religious and economical steps to overcome political and economic problems at home and abroad. Petrushevsky holds that there had been, since the very beginning of the Ilkhanid reign in Iran, struggles between the Iranian bureaucratic elements and those of the ruling Mongols. The Iranian bureaucrats were more inclined to a kind of centralized government that had long been customary in Iran and that could exercise a close observation on military and official affairs. On the other hand, the ruling Mongol elements, prone to a nomadic, tent-dwelling life, believed in a dispersed, centrifugal sort of government (Petrushevsky, 1979).

"Centrifugal" Petrushevsky may call it, but not, we must notice, rebellious against the central government, although there exist reports of some tribe's rebellions and demands of autonomy in the Ilkhanid period. A delicate interaction had been established between the military nobles and the Ilkhans. The military nobility without the person of the Ilkhan and Jenghis' family could not be a part of authority and thus had no raison d'etre. In the like manner, considering their political situations and the enmity of the neighboring countries such as Egypt and Ulus Juji (Altan Ordo), the Ilkhans, too, depended on the military nobility and their armies. A result of such mutual dependence was the Ilkhans' silence against the Mongols' ambitious deeds, giving them a free hand in plundering and oppressing the people. The greedy Mongols financially pressed the people in various ways, especially by exacting heavy taxes from them. Sources mention forty five tax and financial commitment terminologies in the Ilkhanid period, people's lifelong haunting obsessions, indeed (Petrushevsky, 1979). The arbitrary and disorganized approaches to exacting taxes, the corrupt financial system, and the local rulers' inaction and greed incurred more and more destruction upon the inhabited territories. On the great pressure and oppression the tax-collectors inflicted on people in various parts of the country, causing their flee from home and land, Rashid ad-Din Fazlullah writes: "In some towns and villages the military commanders and tax-collectors doubly outnumbered the tax-paying subjects." Rashid ad-Din adds: "A procession of 17 tax-collectors went to 
the large countryside of Firoozabad to get taxes and spent three days in search of tax-payers, but not a soul did they find there. A deserted place had Firoozabad become due to the officials' cruelty." (Fazlollah Hamedani, 1994)

The Mongol local rulers' greed and demands were insatiable, so that nothing was paid to the central government's treasury, which resulted in a large deficit. Pressed with financial problems for its general and even everyday affairs, the government did often try its hand at confiscating people's properties. Unfortunately, some Iranian personages, promising their Mongol kings that they could increase to the budget and eliminate the deficit, reached higher positions, such as ministry, in the Mongol government. Sa'dal-Dawla, the minister of Arghun, and Sadr-ud-Din Zanjani, Geikhatu's minister, were among those who reached their positions by promising to rebuild the finances.

Besides the heavy taxes, the Mongols' land property policies too had pressed the farmers and villagers. Living a nomadic life, the Mongols, however, needed pasture lands for their sheep and cattle. For such a purpose and under their tyrannical rule, they seized the farmers' lands, which they called 'yourt', leaving them no lands or rights whatever. Added to such land possession, they had introduced other types of possessions, of which one was called inje or 'injü'. Scholars know this word to be of the Mongolian origin meaning 'royal estates' (Lambton, 164). 'Injü' lands were vast and, at times, were made vaster by the confiscation of the lands of those in disfavor. An instance of such confiscations occurred when Arghun Khan killed Shams al-Din Juvayni, the sahib-divan, (Minister of Finance). Shams al-Din's properties, writes Vassaf in 1294, ten years after Shams al-Din's demise, were so vast that the income of the now 'Injü' lands amounted to 360 ' tomans' (3600000 dinars) (Wassaf, 1992). Thus such Mongol cruelty of heavy taxes and land appropriation may vividly depict the misery of the Iranian rustics and the economic depression in the Ilkhanid period.

\section{Ghāzān and His Reforms}

One major factor of difference between the Ilkhans and their Iranian subjects was that of religion. On arriving in Iran the Mongols were Shamanists, and then, for unknown reasons, were inclined toward Buddhism, and built many a temple and idol house in Iran. Obviously Shamanism and Buddhism were in sharp contrast to Islam and, naturally, mutually exclusive. As a result, the relations between the Mongols and Muslims were based on distrust, a circumstance that lasted until Ghazan Khan came to power and, at the hand of Sheikh Sadruddin Ibrahim al-Hamavi, embraced Islam. This is a turning point in the history of the Mongols in Iran, amply studied in its different dimensions. Reports of Ghazan's Islamism indicates his firm belief in the new religion, but it was not just a love of Islam that made him make such a big decision. The conditions in different parts of the kingdom, too contributed to his conversion. The secret of the state's survival lies in its ability to undergo reforms and its adaptability to the sociopolitical conditions of the time. A state losing connection and harmony with local and universal changes may not develop effectively and soon disintegrates if it biasedly ignores what is going on in its whereabouts. Ghazan's conversion to Islam was an admission of what changes were happening in his kingdom. It not only lengthened the Ilkhnid dynasty in Iran but also so heightened its power and authority that it terminated its dependence on the court of the Khagan.

With Ghazan embracing Islam, many Mongol multitudes gradually converted to Islam, too. Accordingly temples and idol houses were destroyed (Hamedani, 1994). Racial and class discrimination ended in Iran with the Mongols conversion to Islam. The Ilkhan was not now such an especially distinguished man of high nobility. He was now obliged to adopt measures to bring about a nation's social and political homogeneity. The Mongols long rule and their wanton cruelty in Iran necessitated some radical changes in the system. Ghazan's major reform was Iran's economic revival. New measures in tax collecting being carried out, the Iranian farmers and Mongols coming into the possession of cultivated and uncultivated lands, and the state encouraging and supporting agriculture, all lay the foundations for the reconstruction and revival of Iranian villages and countryside.

Ghazan's reforms not only positively influenced the Iranian farmers' life but also introduced changes into the life of the nomadic Mongols. One step he took to calm down the disturbances was to dedicate the income of some 'injüs' to a specific ordo (camp), so that it would meet its needs from the land and from the taxes collected from the adjacent county (Hamedani, 1940). This made the nomadic Mongol nobility dependent on the Iranian urban and rustic societies, a result of which was the revival of cities and economic production centers.

To reduce pressure on the agricultural sector, Ghazan sought other strategies, too. As it were, the Mongol tribal nation, basically having a military structure and organization, and not classifying tribespeople into military or civil, considered itself primarily a nation of warriors, and in its early invasions on civilized lands, all tribespeople, including men, women, and even slaves, took part in the battles. Confined within the borders of Iran and China and coexisting with sedentary societies, the Mongol tribesmen gradually divided into military and non-military 
groups. When Ghazan Khan reigned, the Mongol Ordo and the Mongol army existed separately. Ghazan Khan could partly solve the military sections' financial problems by dedicating the 'injü' taxes to them, but the non-military ordo, who depended on the army anyhow, needed attention, too. To solve this problem Ghazan first tried issuing Barats (or money drafts) on behalf of the army in various counties. The military forces had to use violence on people to obtain the money, and under various pretexts often elicited more amounts than due. The governors and tax collectors too usually delayed the payment of these Barats. As a result the military men possessed only bad barats, which they usually sold at half price to the expenditure managers (idajis). People didn't fare any better now, nor did the military people earn enough. To amend this, Ghazan ordered that in all winter and summer provinces agricultural yields be stored in barns and then divided by the local ruler between the soldiers. This system produced no desirable results as only a few of the military section received their share, and, on their summer and winter expeditions, the military forces still oppressed the subjects. The attempts to financially support the sedentary people and to provide for the army's expense having failed, Ghazan turned to the old Iqtā system (Hamedani, 1940).

The Iqtā was a fiscal system to pay the soldiers' and the bureaucracy's salaries. Iqtā was, in fact, a piece of land, the revenue of which was allocated to somebody to have his own assigned allowance and to pay for the expenses of the individuals under him. Iqta had been operating in different forms and under different regulations since the Abbasid period, and the independent governments of the Buyids and the Seljuqs had formerly employed it to pay the court and the soldiers. Studying the seljuq sources, especially the Siyāsatnāma of Khwaja Nizam al-Mulk Tusi, we become familiar with the different types of Iqtā allocation to the royal family, the court and the soldiers. In collecting taxes and on what and how they should be expended, Iqtās ran under specific rules. A big threat to this method of paying salaries, increasing especially when the central government became weak, was the muqta's (Iqtā holder) attempt to change the state of the Iqtā to private ownership. Central governments, employing the Iqtā system, could, to some extent, evade the fiscal load of the management of the army, shifting it upon the muqta, who was also responsible for the security of the province under his rule.

The Mongol invasion disorganized the land property structure of Iran, whether it was private, state or waqf property. When Hulegu Khan's rule started in Iran and the Mongol kingdom extended to her western parts, certain measures were taken to provide for the maintenance of the Mongol Ordos. Some territories were assigned as pasture land, or 'yourt'. The warrior Mongols, just content with their horses and cattle put to grass, did not care for the ownership of the lands and soon migrated to other places. The nomadic Mongol nobility did extend and develop their 'yourt's, but just to graze their animals there, and had no mind to legally possess them. The nomadic Mongols fattened their animals on the allocated lands, and let them eat up the farmers' crops and other agricultural products. Such activities converted farm lands into waste lands and, when the villagers deserted them, left the villages in an entirely deplorable state. The central government, too, suffered from this lifestyle, as agriculture, its main source of revenue, was on the verge of annihilation. Some Ilkhans, like Arghun, tried to prevent more damages to the agriculture by paying salaries, or allotting the income of a certain province to the ordos. His attempts, however, were all in vain. Ghazan, too, as was mentioned, tried his hand, though unsuccessfully, at solving the problem, but had to turn to the Iqta system. The allotted Iqta provinces were those on the routes by which the Mongols did their summer and winter passages. The military then took possession of these territories and by the income obtained from them provided for the logistical expenses of the army.

What Ghazan did in this respect seems to have been welcomed by the military section since within only two or three months the Iqta system spread from the Oxus River to the Egyptian borders (the Ilkhanid kingdom). Ghazan's purpose was not only to recover and develop the agriculture but also to decrease the expenses that pressed the treasury. Ghazan granted lands to the Hazara generals so that they might be divided between tens and hundreds of individuals, and the accounts be registered in books (daftar) (Hamedani, 1994). By such land grants, Ghazan hoped to recover the agriculture and revive rustic and urban life as well as to prevent the disintegration of the army, as the generals were highly concerned about the maintenance of their animals.

Rashid ad-Din has given an exhaustive report on economic reforms, especially on agriculture. The real intent behind forging such reformative economic laws was to further agriculture and to raise the level of the rustic income. In Ghazan's decree, the Iqta laws on the share of the subjects, the militia and the officials, and on the rights of water, land and pasture have been detailed. Ghazan had emphatically commanded that "the farmer subjects of each village cultivate in their own locality that the troops might not, on the pretext of holding an Iqta, treat them as slaves, and that the troops might be prevented from starting a farmer's life. The army generals were responsible for the proper enforcement of the Iqta laws. To encourage the farmers to further develop the lands, it had been assigned that the farmers' yields be measured each year so that they might be rewarded for their high production or be punished for their negligence. This decree of Ghazan was in accord with the interests of the 
Mongols, who, at the time, as Rashid ad-Din Fazlullah reports, had taken a fancy to landed property and cultivation (Hamedani, 1994). An inference from the contents of the Ta'rikh-i Mobarak-i Ghazani informs that the iqta lands were not to be sold or given away as gifts, but could be inherited.

Ghazan's reformations in agriculture and Iqta holding had its blessed effects. For one thing the problem of the Mongols' sheep and cattle grazing was partly solved, as the borders of their allotted pasturelands were demarcated. For another, their cash needs were thus met, leaving them independent of the treasury. Thirdly, the people were, to some degree, free from the Mongols' transgression as the Mongol survival depended on the favorable conditions provided for the farmers' work. And, finally, the rustic population set down to reviving the lands and once more farming and agriculture thrived.

Ghazan had no mind to have the Mongols living a farmer's life but, gradually changing their military nature, they took an interest in land and agriculture and finally became agriculturists. Mostowfi reports that around the cities of Kaghazkonan and Sojas, there are villages the Mongol residents of which are engaged in agriculture. (Mostowfi, 1958)

Ghazan's agricultural reformations inclined the Mongols toward a sedentary lifestyle but his reconstruction of the dilapidated towns, development of the existing ones and building new ones did make them adopt it. However, to what extent were such developmental measures effective in their shift of lifestyle it is not quite known. Ghazan started his reconstructions at a time when almost half of the people's houses had been ruined in the Mongol invasion, and all attempts for residence reconstruction had proved ineffective (Hamedani, 1994). Other Ilkhans before Ghazan had set up buildings, but they received no regular maintenance and over time went to ruin through negligence (Hamedani, 1994).

But Ghazan showed a serious interest in the reconstruction of the broken down places and building new towns, the amount of which has been recorded by many of Ghazan's contemporary historians. Persian high officials and ministers such as Khwaja Rashid ad-Din Fazlullah, whose account of works cannot be contained in this short study, had been, of course, very influential in such matters. Cities built at Ghazan's order include Mahmudabad, Ojan and Ghazaniyeh. Mahmudabad was built in Mugan plain, in the Gavbari plain, along the coast of the Caspian Sea and was considered the usual winter residence of Ghazan. The city degenerated after Ghazan's death and was a small town at the time of Mostowfi (Mostowfi, 1958).

On the ruins of Ojan, which had been ruined by the Mongol invasion, was built, under a new name, the city of Shahr e Islam in 1299 (Wassaf, 1959). Ghazan set up a great golden canopy in the center of the city (Fazlollah Hamedani, 1994) and other rulers also built houses, gardens and markets.

The city of Ghazaniyeh, built in Iraq, was another work of Ghazan. As a result of excavating and building a canal between Baghdad and Al Hilla, an area known as Alghami developed, too and within two years, a city, later to be called Ghazaniyeh, flourished in it.

Ghazan did not just order the building of cities; he was also quite active in planning and architecting cities and buildings. When in repairing the baileys and battlements of the city of Tabriz he received different suggestions on the locations and limits of the walls, he ordered the length of the walls to be so extended as to not only adjoin them with the suburban gardens and farms but also to provide for the settlement of probable immigrants.

Ghazan had truly set his mind on building monuments, so he much benefitted from the rich people in the society and employed skilled architects, as he did in building Shanb Ghazan, a district in Tabriz. Sharing ideas with his architects, he introduced architectural changes in building his own mausoleum, too.

The book Jami al-tawarikh, registering the forty decrees and steps that Ghazan issued and took on construction, includes one chapter on the development of cities (story no. 12), and one on the recovering and revival of barren lands and ruined cities for the settlement of people (story no. 37). In Gazan's reign, the reconstruction of cities moved at such a fast pace that a thousand houses were built in a year, and at fixed prices, too. A difficulty hindering Ghazan's reconstructions was that people did not heartily welcome and contribute to the recovering and reviving barren and disinhabited areas. It seems that the people and land developers' disinclination in this matter was rooted in the fear that the government might claim ownership to their newly built properties. Perceiving this, Ghazan introduced new conditions that converted, in a short time, the ruined uninhabited areas into constructed inhabited areas. He omitted and in some cases decreased the taxes, which encouraged people to take part in the reconstruction of the ruins. He also issued a document, the contents of which permitted the ownership of the newly built by inheritance. A new Divan (governmental office), called Divan Khalessat, was established by Ghazan, which not only supervised granting lands to people, but also greatly contributed to the development of cities. Ghazan gave a similar right to the Mongols so that they develop lands in their 'yourt's but 
his emphatic command demanded that the Mongols work themselves, and prevented them from abusing the common people and slaves in such developments. Ghazan also commanded that development reports be presented to him every two years so that those who had cheated and underworked in their jobs be duly punished (Hamedani, 1994).

Oljaytu, Ghazan's brother and successor, too, took an interest in constructional work and built cities and districts in various places in Iraq and Azerbaijan. His developmental attempts resulted in trade prosperity and gave a higher quality to urban life; many more Mongols took up settlement in cities.

The extent to which the Mongols were attracted by the city life and settlement may not be exactly surmised. However, from the contents of Ibn Battuta's travel book, The Journey, one may infer that many Mongols had inclined to sedentary life in cities. He visited the cities of Azerbaijan, including Tabriz, eighteen years after Ghazan had died, and reports of Mongol families, all robed in costly garment, strolling the markets of Tabriz, buying expensive cloth and jewelry (Battuta, 1969). His reports include, in addition to the Mongol city settlement, accounts of their changing their traditions, and of their welcoming the Persian lifestyle. To the Mongols of the Genghis Khan's era, luxury was sable's pelt and silver cradle, but a century after the great Khan's death, the Mongols had turned to collecting jewels, wearing costly clothes and setting up lamé tents.

\section{Conclusion}

The beginning of $7^{\text {th }}$ century Hijri $\left(13^{\text {th }}\right.$ century AD) witnessed the civilized world being harassed with the invasions of some nomadic Mongol tribes whose only motives were to massacre, rob and destroy. They lived and acted under a culture so incompatible with those of the conquered nations. Massacring people and destroying cities naturally created a great gap between the people and the Mongol government. As a result of a series of problems and difficulties, the Mongols discontinued their imperialism, and the Mongol aristocrats decided to settle in and confirm their hold on the conquered lands. To create an atmosphere of trust in Iran was the first step that the Mongols had to take, but the Persian pessimism and the conquerors' adherence to their own customs and traditions impeded the process of trust making. The old Mongol culture, which was based on nomadism, and the Yasa (the Mongol sacred code) were among the most important factors causing the gap between the two cultures. Finally, after periods of ups and downs in the Mongolo-Persian relationships, the Mongol rulers gradually succumbed to the tastes and demands of the more civilized Persian culture, and with Ghazan's accepting the religion of Islam, most Mongol cultural ties with central Asia were broken. The Mongol nomadic lifestyle, however, lingered on. The coercive Mongols who had, for a long time, made a living by plundering and pillaging were now entrusted with the new responsibilities: Safeguarding the subjects against oppression and cruelty, guarding the roads, and wiping out the thieves and highwaymen. Such an entrustment demanded an able management and depended on allocating a sufficient budget. Ghazan, an outstanding figure in the line of the Ilkhans, had enough power and authority to entrust these responsibilities to the military Mongols. To provide for the cost of putting his plans and programs to practice, he took up various approaches, which finally ended in the Iqta policy. This policy ensured the rights of the Mongols and in a short time converted the hunting nomadic Mongols into settled farmers. His policy for constructing and reconstructing cities also contributed to the Mongols' adoption of their new lifestyle. This social change in the Mongols' life happened mostly in Azerbaijan, but other places in the Mongol kingdom, like Ulus Chagatai (Chagatai Khanate) persisted in following their old nomadic lifestyle.

\section{References}

Al Kashani, A. A. M. (2006). In M. Hamboli (Ed.), Tarikh Oljaytu. Sherakat Elmi v Farhanki, Tehran.

Al Hamavi, Y. I. A. (1970). Mu'jam Al-Buldan. Mtbae Alseade, Cairo.

Anonymous. (1998). In Paul Kahn (Ed.), The Secret History of the Mongols. Cheng \& Tsui.

Aqsarayi, A. K. (1944). In O. Turan (Ed.), Musamurat al-Akhbar Tarikh-I Salajuqeh. Turk Tarih Kurumu Basimevi, Ankara.

Barthold, V. V. (1944). Turkestan Down to the Mongol Invasion (Turkestan namī). Akah, Tehran.

Bayani, S. (2001). Mongols v hokomatī İlkhani dar Iran (The Mongols and Ilkhanid rule in Iran). Samt, Tehran.

Beazley, C. R. (1903). The texts and versions of John De Plano Carpini and William De Rubruquis. London: Primted for the Hakluyt society.

Grousset, R. (1990). Empratori sahranavrdan (The Empire of the the Steppes). Sherakat Entesharat Elmi v Farhanki, Tehran.

Hamidāni, R. A. D. F. A. (1970). In B. Karimi (Ed.), Jami' al-tawarikh. Iqbal, Theran. 
Ibn Battuta. (1969). Safarnamah - I-ibn - Batutah.Tehran. Bungah-1 tarjamah va Nashr-1̄ kitab, Tehran. Ibn - Athir. (1966). Al-Kamil. (Vol. 12). Elmi, Tehran.

Juwayni, A. M. (1992). In M. Qazwīnī (Ed.), Ta'rīkh-i- Jahān Gushā (Vol. I\&II). Arghavan, Tehran.

Lambton, A. K. S. (1997). Landlord and peasant in Persia( Malik va zarī dar Iran). Sherakat Entesharat Elmi v Farhanki, Tehran.

Mustawfi, Q. H. (1958). In M. Dabirsiaghi (Ed.), Nuzhat al- Qulub .Taha, Tehran.

Petrushevsky, I. P. (1988). Ta'rīkh-i- ejtemai eghtesadi Iran dar dore Mongol. Etelaat, Tehran.

Razavi, S. A. (2012). Shahr v eghtesad dar ahde İlkhanan. Amir Kabir, Tehran.

Saunders, J. J. (1994). The History of Mongol Conquests. Amir Kabir, Tehran.

Wassaf, S. D. A. A. S. S. (1959). In M. M. Isfahani (Ed.), Tarikhe wassaf. Moasse Motaleat v Tahghight Farhanki, Tehran. 